\title{
THE PURIFICATION OF SEWAGE BY BACTERIA.
}

\author{
By Sander Rideat, D.Sc.Lond., F.I.C.
}

(Memirer.)

Read at Sessional Meeting, December 9th, 1896.

WITHIN the last few years considerable attention has been given to methods for dealing with the sewage problem, which present considerable points of difference from those which have hitherto been considered most efficient, and members of The Sanitary Institute had already had an opportunity of discussing this subject a year ago, when Sir Douglas Galton opened one of these discussions on the lessons to be learnt from the experimental investigations by the State Board of Health of Massachusetts upon the purification of sewage. It must not be forgotten that although these American experiments have been a great stimulus to fresh work, with a view to perfecting what may be called a natural process of dealing with sewage, that the Rivers Pollution Commissioners more than twenty-five years ago came to very important conclusions upon the filtration of sewage through soils and artificial filter beds, which are true at the present time. Even at that date, the chemical treatment of sewage was known to determine little more than the rapid deposition of the suspended organic matter, therefore it had to be followed by a natural purification of the effluent by treatment on land before the purification was sufficiently complete for the effluent to discharge into a river. As the main problem is the removal of the organic matters in solution, it would seem that chemical treatment after all plays a very small part in the complete removal of impurities, and most chemists can cite numerous examples illustrating the really insignificant value of the work done by chemical treatment.

Thus, quoting from Dr. Frankland, in his summary of the work done in the laboratory of the Rivers Pollution Commission: "All classes of processes are to a great extent successful in removing polluting organic matter in suspension. As might be expected the filtration processes are in this respect the best, irrigation ranks next, while chemical processes are somewhat less efficient for the remoral of suspended organic matters. 
But the getting rid of suspended matters is a simple problem compared with the removal of organic matter's in solution. It is here that the different processes experience the most severe trial, and it is on the application of this test that the great superiority of downward intermittent filtration and of irrigation over upward filtration and the chemical methods of treatment, becomes strikingly apparent. Thus, in romul numbers it may be said that on the arerage the processes of downward intermittent filtration and irrigation remove from the soluble constituents of sewage twice as much polluting matter as that got rid of by the processes of chemical treatment and of upward filtration." I have quoted this paragraph at length as it clearly shows the close analogies in the results then obtained between irrigation and intermittent filtration on the one hand and between chemical treatment and rpward filtration on the other hand.

At that time irrigation on sewage farms was believed to be capable of affording a "hopeful prospect of a return of the cappital invested," and altlough considerable opposition has almost invariably been met to the creation of a sewage farm, on the ground that it was likely to be injurious to health, experience has shown no sound reasons for such a contention, and combined chemical and land treatment has now become very general. Experience has, however, also shown in most cases that the reason of the adoption of sewage farms in place of intermittent filtration, viz., "of afforting a hopeful prospect of a return of the capital invested," is not warranted; but that the initial cost of the necessary land, and the poor return on the crops grown, make it at the present time decidedly advantageous to adlopt the alternative of intermittent filtration.

Owing to the fact that upward filtration gives such indifferent results compared to intermittent filtration, little more was heard of it, and it had been almost forgotten that upward filtration was capable of giving similar results to chemical precipitation, until the new bacteriological processes had again drawn attention to the subject. The chemical methods, although somewhat improved during the last twenty years, have been found expensive to work on a large scale, and even now it is true that the "resources of science hold out no hope that the foul matters dissolved in sewage will be precipitated and got ria of by the application of chemicals to the offensive liquid," so that here again the alternatjve of "upward filtration" seems worth consideration.

Reviewing the opinions of the Royal Commission of twentyfive years ago, it seems strange that chemical precipitation and subsequent land treatment should have almost entirely taken 
the place of the clouble alternative, viz., upward filtration followed by intermittent downward filtration.

Even in 1870 it was known that upward filtration of London sewage through sand and sand and chalk gave some purification, although there was no aeration of such a filter, and that the best results were obtained when the rate of filtration did not exceed $5 \cdot 6$ gallons per cubic yard per twenty-four hours.

We have then in upward filtration a method of partially purifying sewage which is independent of the air supply, and which gives the best results when the passage through the filter is slow. In Mr. S'cott-Moncrieff's cultivation tank we have both of these conditions, and with the exception that we now know that the action is bacterial rather than mechanical, the process is practically identical.

The introduction of flints or stones into the cultivation bed impedes the rate of progress of the fluid through the tank and forms surfaces on which the organisms concerned in the chemical changes grow, and I think no one who lias carefully studied the results obtained can fail to admit that a purification has been effected which mechanical filtration alone could not possibly account for.

The dissolution of the suspended solids which also takes place in such a cultivation tank is also capable of being explained on similar grounds, as not only have we the well-known fact that such solids do disappear in cesspools and when buried in land, as lits been recently insisted upon by Dr. Poore in dealing with rural sanitation problems, but their destruction had also been noticed by $\mathrm{Mr}$. Waring in his "strainers," as well as more recently by Mr. Cameron in his "septic tank" at Exeter. It is necessary, however, to clearly distinguish between the changes which take place in upward filtration, in slow passage or rest of sewagre, or on such strainers as clescribed by Mr. Waring, and what subsequently takes place when the efthent is subjected to the influence of atmospheric oxycren. The first process is one of hydrolysis, in which chemical changes are effected by means of organisms or their enzymes without the aid of oxygen, the second is one in which oxidation is effected by organisms in presence of free oxygen.

As an example of the former of these changes may be mentioned the conversion of urea into ammonium carbunate, and as urea is the principal constitucnt containing nitrogen present in the raw sewage, this change is one of fundamental importince.

$$
\mathrm{CO} \mathrm{N}_{2} \mathrm{H}_{4}+\mathrm{OH}_{2}=\mathrm{CO}_{2}+2 \mathrm{NH}_{3} \text {. }
$$

The conversion of insoluble albumen into albumoses and 
peptones is also a well-known example of such change brought about by enzymes in the absence of oxygen in complex nitrogenous substances. With organic compounds containing no nitrogen, the conversion of cellulose and woody tissue, practically insoluble in water, into starch, which is acted upon by hot water, and finally into sugars which are mostly readily soluble in water, is a well-known hydrolytic change. All these changes take place without any oxidation properly so-called, and when carbonic acid is produced during such fermentation, it is formed not from the addition of any atmospheric or free oxygen, but from the oxygen already existing combined in the organic substances or water present.

It necessarily foilows from these considerations that if such liychrolysis does take place, an increase in the free ammonia and carbonic acid in the treated sewage will be noticed, and possibly under some conditions more organic nitrogen and organic carbon will appear in the solution; and that, therefore, an analysis of a sewage before and after such treatment, if judged in the ordinary way, would lead to condemnation insteal of a favourable opinion. I should like, also, to take this opportunity of pointing out that the albuminoid ammonia found by the ordinary methods of analysis gives a measure of the casily broken up organic nitrogenous compounds present, and that consequently an increase in the amount may in some cases be regarded as a favourable sign, since it points to the resolution of stable nitrogenous compounds into simpler ones.

As I have recently had an opportunity of examining the most recent of these proposals for dealing with the solids present in sewage, on a thoroughly practical scale at Exeter, it will not be out of place if I refer to it at somewhat greater length, especially as I believe no complete account of what are now known as the Exeter experiments has been published.

The construction of the septic tank, into which the sewage flows, preparatory to passing into the filter beds, is shown in the accompanying illustration (Plate I., page 64), and it and the arrangement of the filter beds is clue to $\mathrm{Mr}$. Cameron, the City Surveyor. It will be seen that it is essentially a closed underground tank fitted with an inspection chamber in the centre, through which the sewage slowly passes.

The present installation at Belle Isle deals with the whole of the sewage discharged from the St. Leonards Sewer, and may be considered as an experimental plant designed to deal with the total sewage of a population of about 2,000 inhabitants, the average daily volume being about 50,000 gallons, or approximately one-twentieth of the total sewage of the City of Exeter. The purification effected takes place in two stages 
which may be conveniently considered separately, the term effhent being given to the product of the septic tank, and filtrale to that of the subsequent filter beds.

1. Changes in the Septic Tank. The present septic tank has a working capacity of 53,800 gallons, and therefore holds approximately a day's supply. In other words the changes effected in the raw seware, as compared with the tank effluent, are due to the sojourn of the scwage in the tank for the period of about twenty-four hours. This period of septic tank change however varies with the volume of the sewage passing, so that a dilute sewage due to rainfall flows through the tank at a greater rate than the average, and during the period of maximum flow a correspondingly greater quantity of tank effluent passes out of the tank.

The variation in the composition of the raw sewage from how to hour and from day to day, owing to the slow rate of flow through the tank rendering diffusion and sedimentation possible, must necessarily be less marked in the tank effluent, so that its composition is of more uniform character than that of the raw sewage. The first change therefore to be noted in connection with the work of the septic tank is the smoothing effect which it has upon the composition of the sewage, and this function of the tank is one of very considerable importance in view of the further disposal of the effluent.

The diminution in the rate of flow of the sewage on entering the tank also causes a deposition of the heavier suspended particles, consisting chiefly of gravel and earth, in the grit chamber. Beyond the grit chamber the sewage flows over a submerged partition into the main chamber of the tank, from which, at the further end, it is drawn off continuously by a "slotted pipe" placed transversely to the flow six inches below the surface.

As the total length of the tank is somewhat more than fifty feet, it follows that with an average flow of 50,000 gallons per day, in and out of the tank, the rate of flow is exceedingly small, and very favourable to the settlement of the finer particles in suspension. A marked clarification of the raw sewage was therefore reasonably to be expected as a result of its passage through the tank.

It is claimed however by Mr. Cameron, that more radical changes than these obvious ones take place in the tank, produced by the bacteria which are present in the raw sewage, whose growth is favoured by the absence of light, air, and the comparative absence of movement. In order to establish this fact, samples of the raw sewage and tank eftluent were taken for analysis hourly in such a way that they were 
proportional to the flow, and representative of the grencral character of the raw sewage and tank effluent. Four average samples of sewage were obtained in this way during the twentyfour hours commencing at $10.20 \mathrm{a} . \mathrm{m}$. on Nov. 3rd. The gaugings showed that 50,9310 gallons of sewage entered the tank during the twenty-four hours, and that consequently it, took twenty-four hours fifty-five minutes for the contents of the tank to be changed, or at $11.15 \mathrm{a.m}$. on Nor. 4th, the sewage taken for this experiment made its reappearance as effluent. Similar hourly samples of the effluent proportional to the flow were taken for analysis during the next twenty-four liours.

A comparison of these analyses shows that the septic tank effects not only the smoothing effect in the composition of the effluent already pointed out as probable, but a very marked alteration in the chemical characteristics of its constituents as (omprarel with that of the raw sewage.

That the contents of the tamk had been proportionally changed is shown by the fact that the average chlorine content. was practically the same in the raw sewage and effluent. In order to more clearly establish the difference between the sewage and the tank effluent, I have calculated the composition of the sewage to a constant chlorine content of 7 parts per 100,000, and the mean result so corrected is as follows:-

\begin{tabular}{|c|c|c|c|c|c|c|c|c|}
\hline & $\begin{array}{l}\text { Total } \\
\text { Solids. }\end{array}$ & $\left|\begin{array}{c}\text { Oxygen } \\
\text { con- } \\
\text { sumed. }\end{array}\right|$ & $\begin{array}{l}\text { Freo } \\
\mathrm{NH}_{3}\end{array}$ & $\begin{array}{l}\text { Alh. } \\
\mathrm{NH}_{3}\end{array}$ & Nitrite. & $\begin{array}{l}N \text { as } \\
\text { Nitrute. }\end{array}$ & Totaln. & 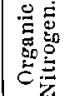 \\
\hline Raw Sewage, Nor. 3,4 & $46 \cdot 8$ & 6.56 & 36 & $1 \cdot 40$ & $0 \cdot 0$ & $0 \cdot 0$ & 7.4 & \\
\hline 'I'aulk Efluent, Nov. 4, 5 & $48 \cdot 6$ & $4 \cdot 32$ & $4 \cdot 9$ & 0.64 & 'ruace & 0.04 & $6 \cdot 24$ & \\
\hline
\end{tabular}

From the above results it will be seen that the changes produced by the passage of the sewage through the tank may be summarised as follows:-

(1) A marked increase in $: 2$ total solids in solution or fine suspension.

(2) A reduction of about 33 per cent. of the organic matter as measured by the oxygen consumed.

(3) An increase of about 33 per cent. in the free ammonia.

(4) A reduction of about 54 per cent. in the organic or albuminoid ammonia, or 50 per cent. in the organic nitrogen.

(5) A slight production of oxidized nitrogen and a disappearance of a small amount of the total nitrogen. 


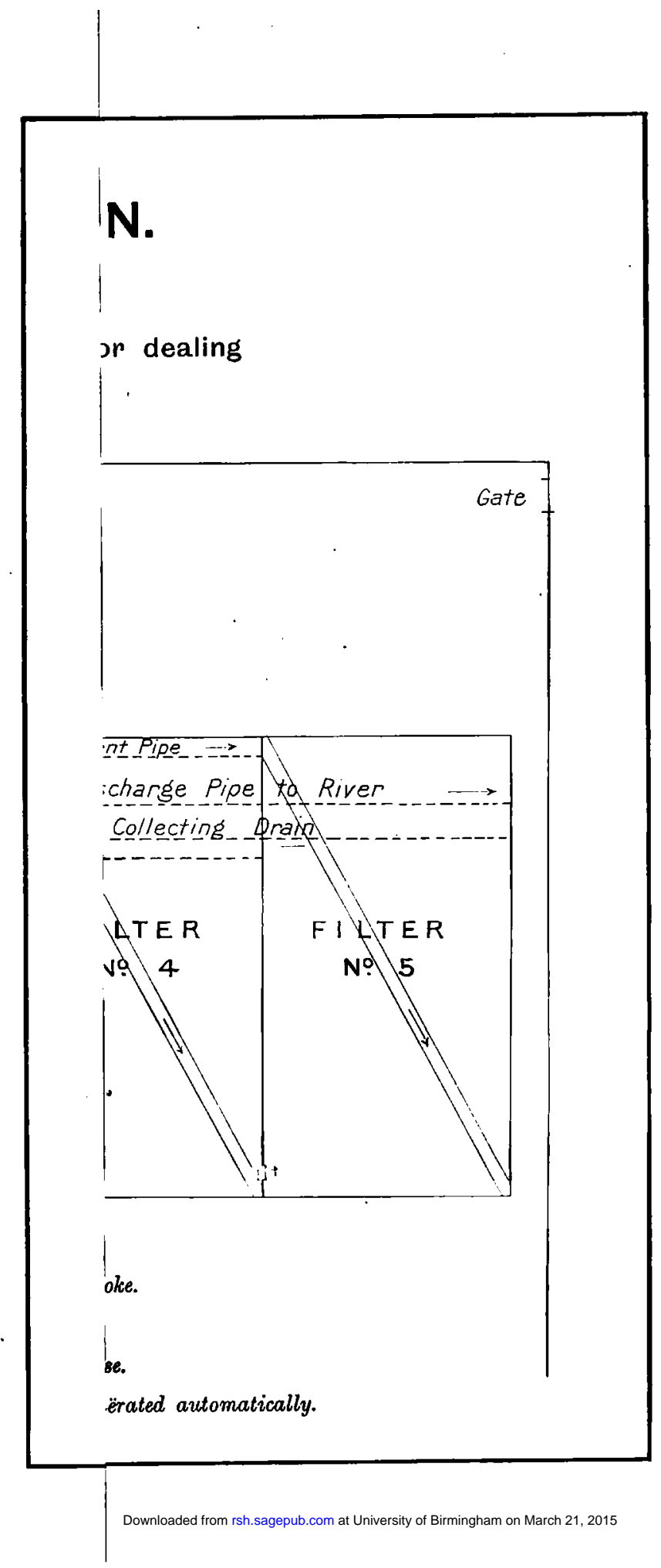

No. 1. 


\section{SEPTIC TANK $F$}

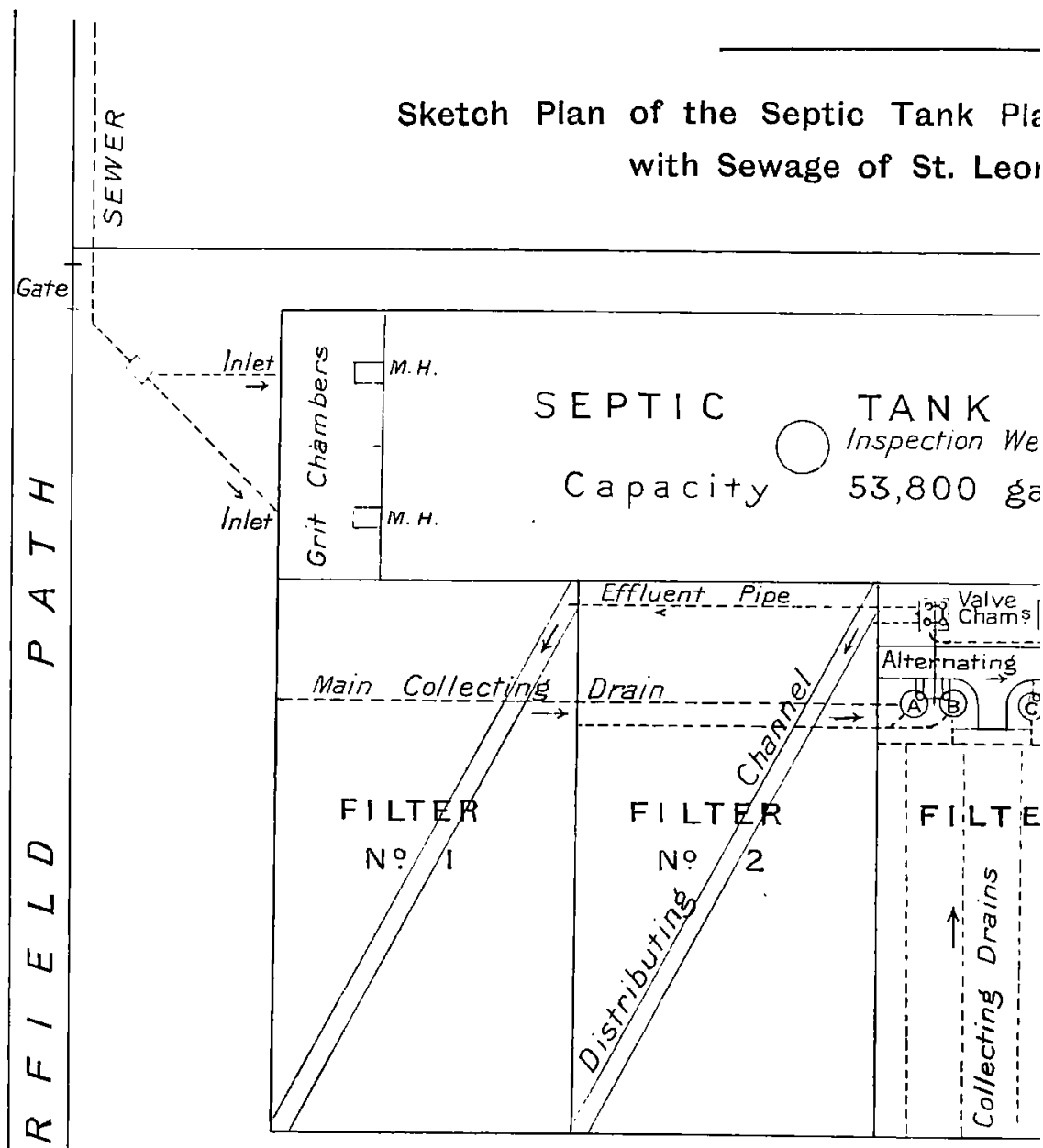

Area of each filter, 80 square yards; and depth, 5 feet $=$ Effluent introduced at start $=0.6$ of above volurne $\therefore 0.4$ Effluent introduced in ordinary working from $8,000-9,00$ $A, B, C, D$ are collecting wells, receiving filtered water fr By means of the alternating gear, each filter in rotation is 


\section{FILTRATION.}

\section{Plant at Belleisle for dealing} Leonard's, Exeter.

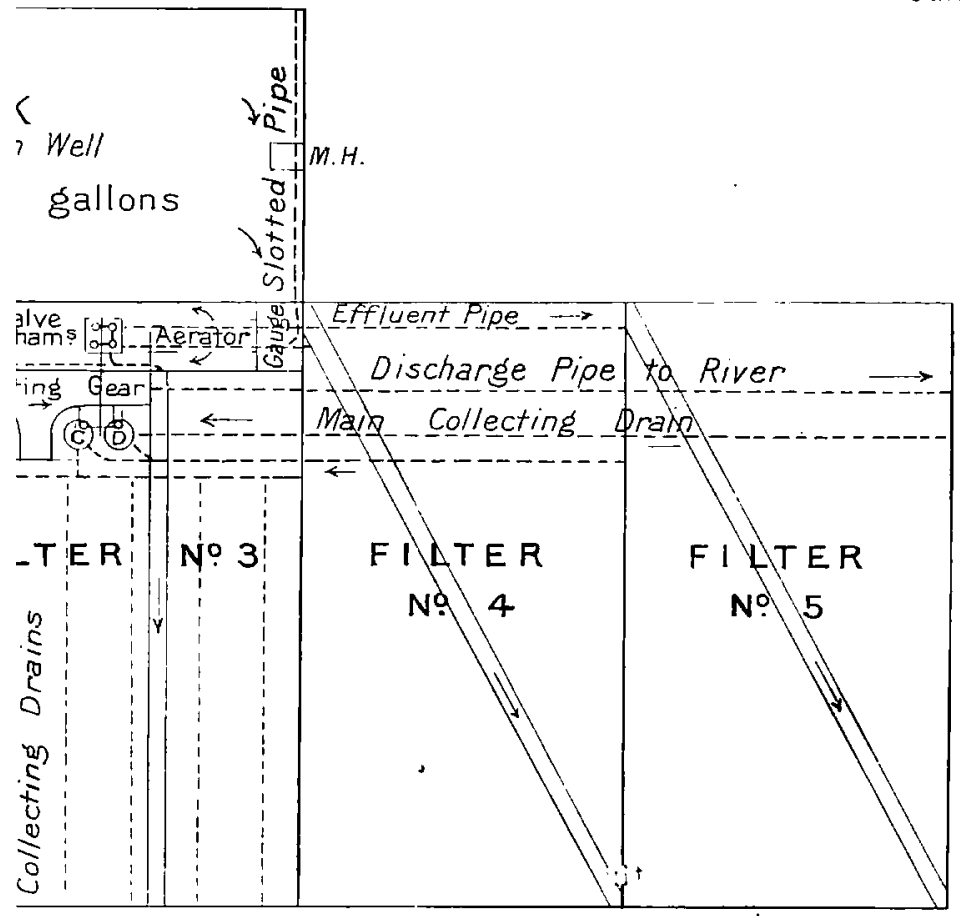

:et $=$ volume 22,500 gallons.

$\because 0.4$ of mriginal volume $=$ coke.

$-9,000$ gals. per filter.

ter from the four filters in use.

ion is flled, discharged and aërated automatically. 


\section{SEPTIC TANK I}

Cycle for four Filters, Nos. 1, 2, 3 and 4, di $A, B, C$ and

At starting let filter No. 4 be already full and resting, and No. 1 filli When No. I fills it overflows into tipper C, discharging No. 4, puttin When No. 3 fills it overflows into tipper B, discharging No. 1, puttin When No. 2 fills it overflows into tipper D, discharging No. 3, puttin When No. 4 fills it overflows into tipper A, discharging No. 2, puttin

\section{Diagram of Overfic}
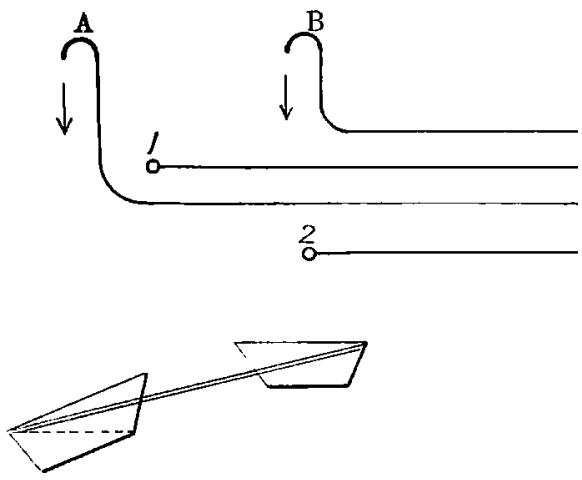

Dlagram showing successive states of Filters correspondir

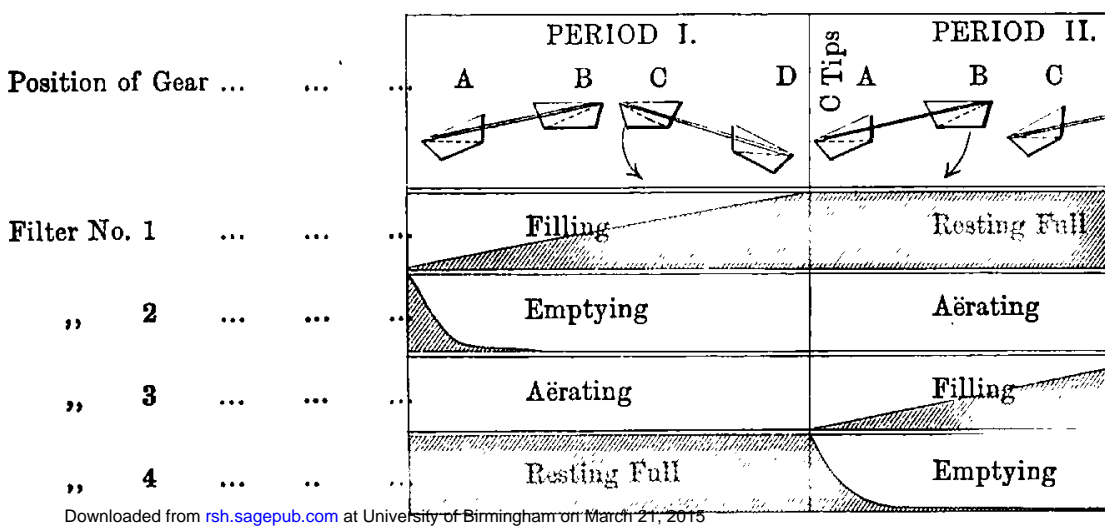




\section{SECTION SHEWING ARRANGEMENT}

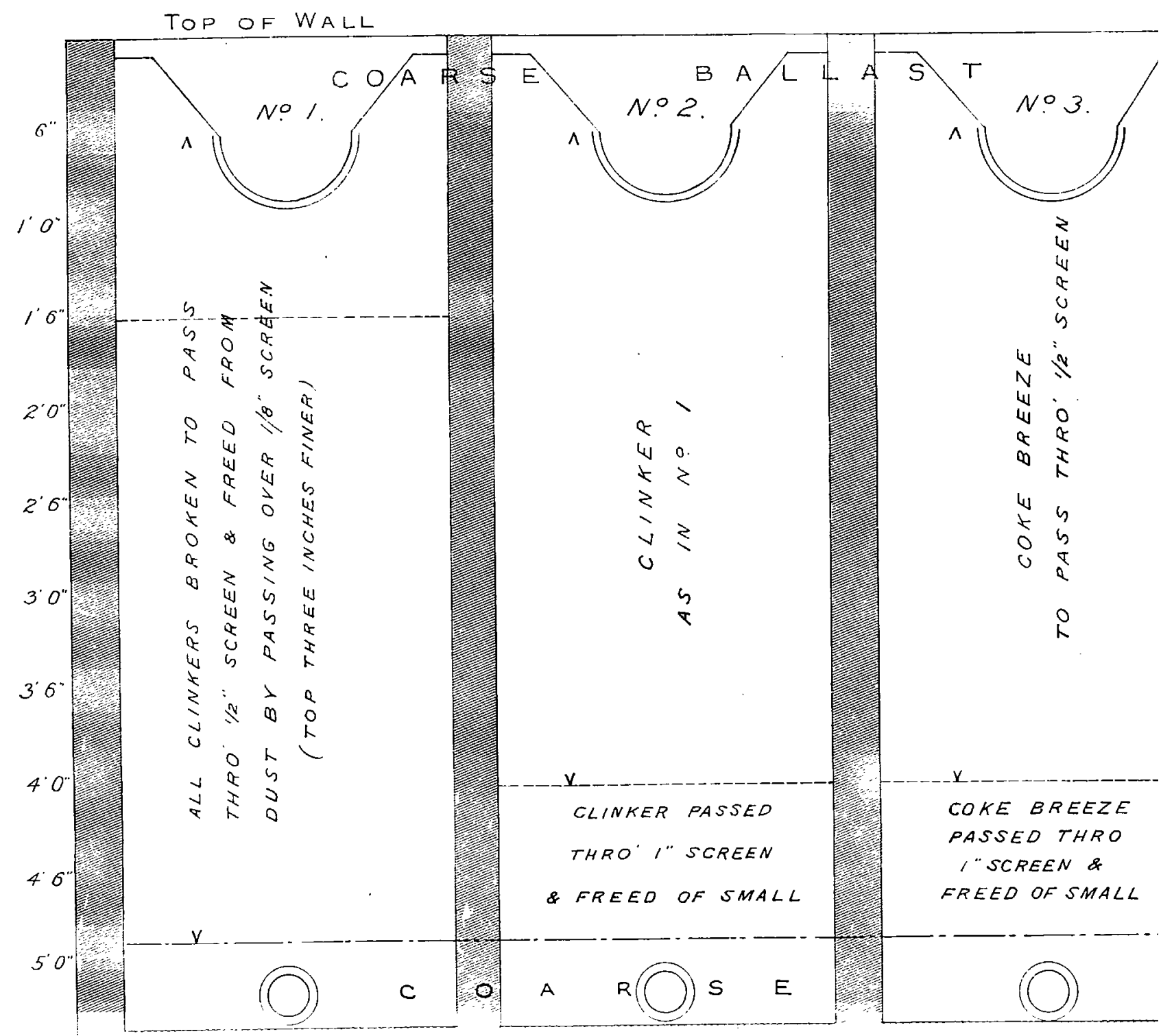


No. 3.

\section{OF FILTERING MATERIAL.}

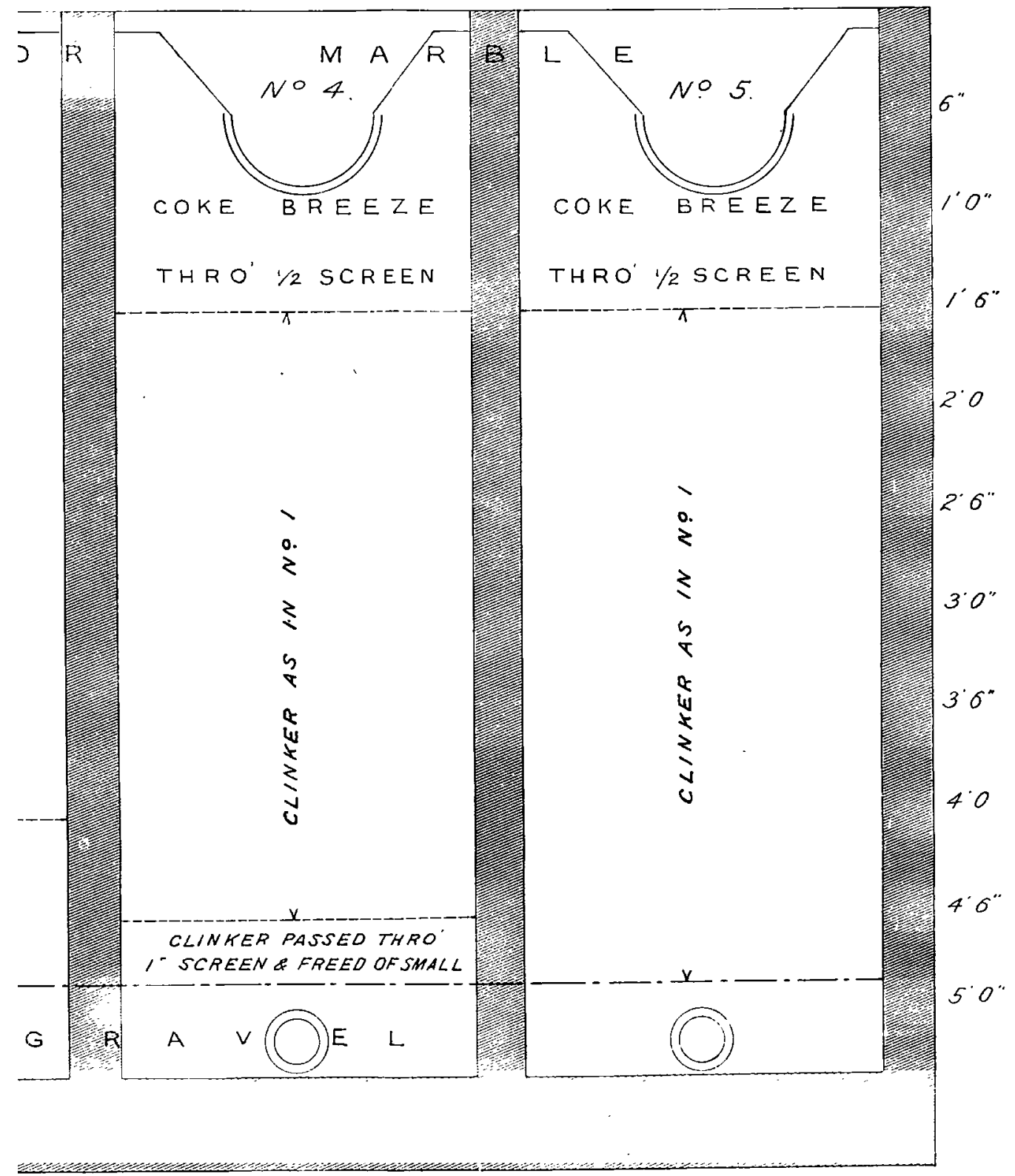




\section{NITRATE CURVES}

足

Nov. 12. Well C. Filter No. 4. Disc Nov. 12. Well A. Filter No. 1. Disc Nov. 13. Well B. Filter No. 2. Disc Nov. 14. Well D. Filter No. 5. Disc

* Filter having rested empty for sol

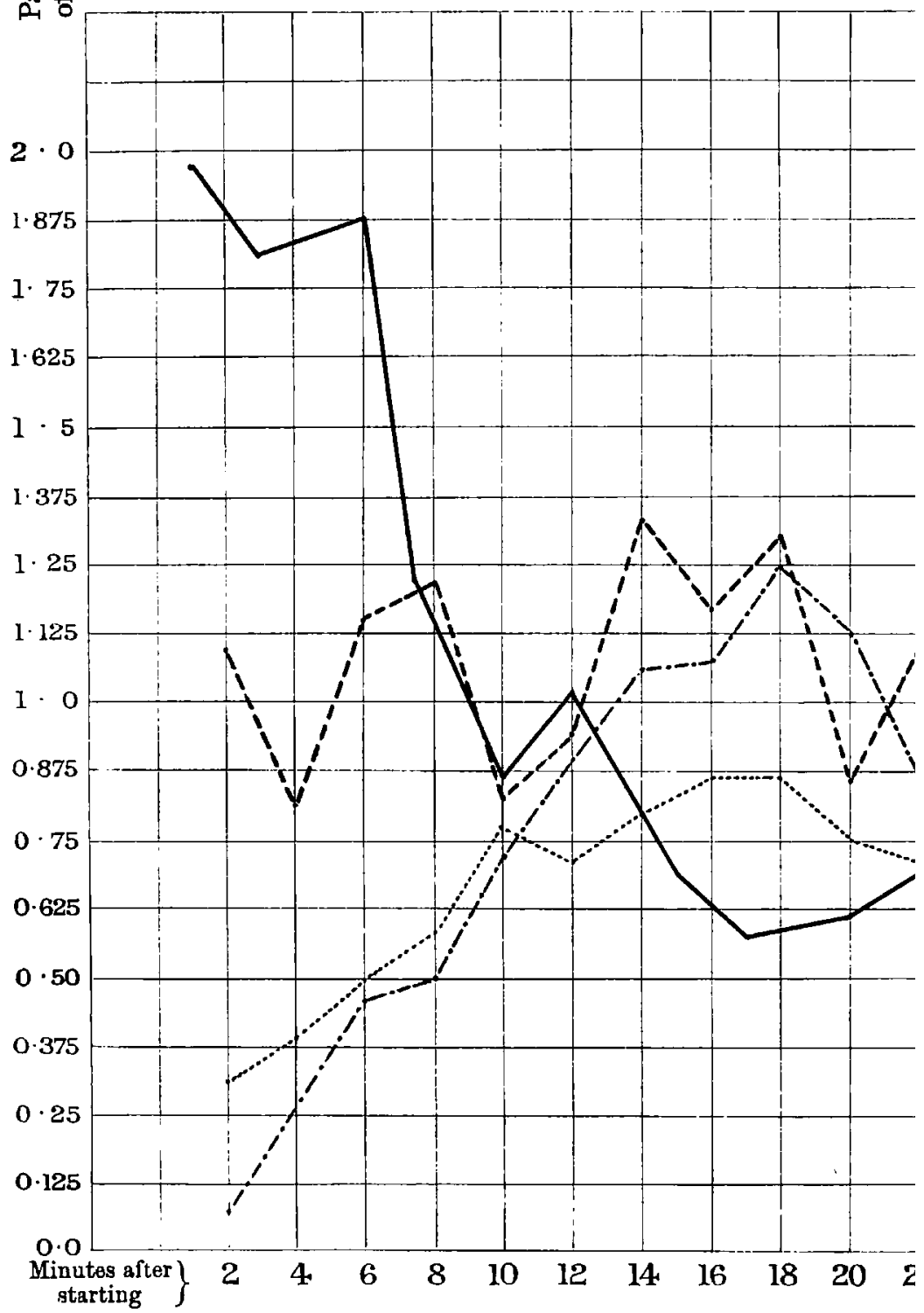


No. 4.

\section{OF FILTERS.}

Discharged at 3.33 p.m.

Discharged at 12 noon.*

Discharged at 12.36 noon.

Discharged at 3.27 p.m.

or some days.

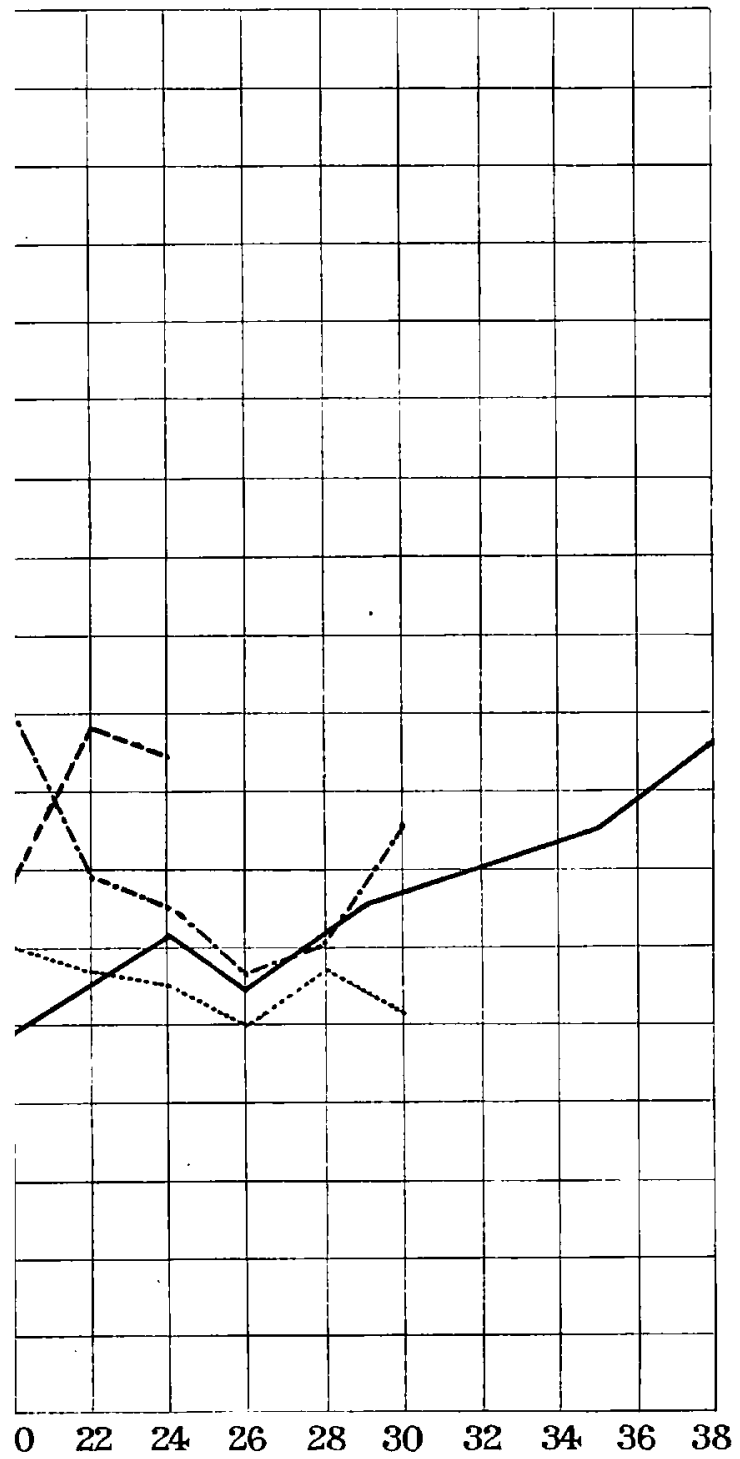


It is therefore evident that the septic tank by means of its bacteria, enzymes, or spontaneous chemical decomposition, materially alters the composition of the raw sewage. The increase in the total solids points to a solvent action of the water on matter in suspension, and this may be due to a digestive or to a purely physical process, but the marked disappearance of organic matter and transference of the nitrogen from the organic condition to that of free ammonia is undoubtedly due to bacterial influences. The above changes should be capable of being confirmed by (1) Evidence of the production of gaseous carbon compounds, either oxidized as carbonic acid, or as hydrocarbons, and ( 2 ) Evidence of the production of nitrogen in a gaseous form, either as free nitrogen, lower oxides of nitrogen, or possibly ammonia which has escaped solution.

The correctness of this was proved by subsequent experiments which established the fact that the dissolved carbonic acid was increased in the effluent, and that carbonic acid gas, nitrogen, marsh gas, and hydrogen existed in the air in the upper part of the tank, which was also found to be entirely deprived of its oxygen.

The raw sewage and the tank effluent were also proved to be devoid of free dissolved oxygen, so that although atmospheric oxygen can leak into the tank, I am of opinion that the amount of direct oxidation in the tank must be very small and that the oxidized compounds produced must be formed from the dissolution or hydrolysis of oxygen containing organic compounds.

Two analyses of the gas obtained (1) from the slotted pipe, and (2) from below the surface of the liquid in the tank are given below; the second sample burnt freely and neither sample contained any oxygen.

Per cent. by Volume.

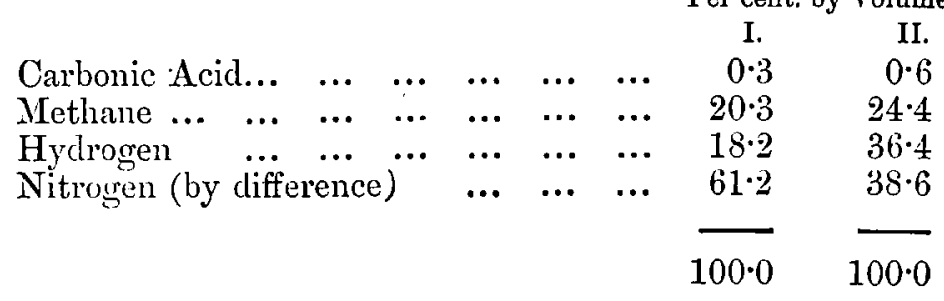

Several determinations of the amount of carbonic acid in the gases of the septic tank showed that from 0.54 to 0.81 per cent. was present, or about fifteen times that in the outsicle air. As the tank was not constructed in such a way as to allow the gases

VOL. XVIII. PART I. 
produced to flow uniformly out of the tank, the absolute amount of gas produced per 50,000 gallons of sewage per twenty-four hours could not be gauged, but it is casy to see that with diffusion taking place, the total loss of carbon and nitrogen per day may be very considerable. A further and more distinct proof of the large amount of organic carbon which disappears in the tank is given by the fact that the dissolved carbonic acid was greater in the tank effluent than in the raw sewage.

Thus the carbonic acid produced in the tank effluent was determined and found to average 8.8 parts of carbonic acid per 100,000 , or $12 \mathrm{lbs}$. of carbon per 50,090 gallons discharged. $\Lambda$ s on this particular day 62,238 gallons discharged, the abore amount of carbon should be increased to about 15 lbs. to represent the loss of carbon on this day.

Table showing Amount of Carbonic Acid formed in Tank.

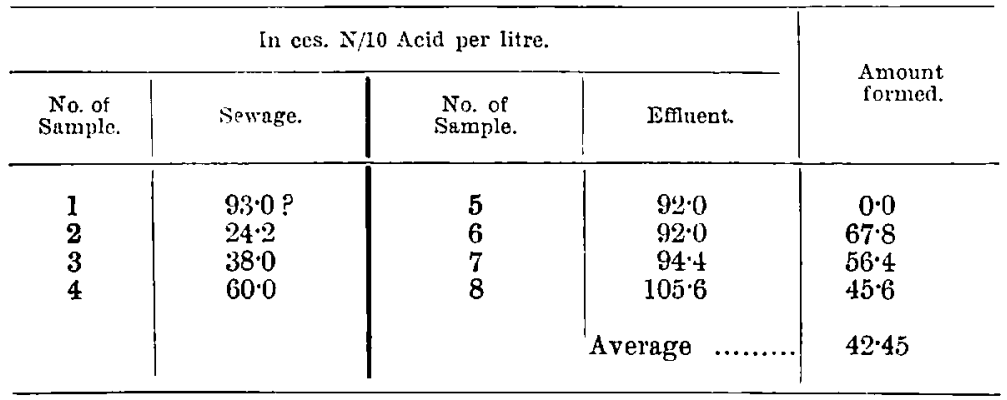

Amount of Carbonic Acid Gas in the Air of the Septic Tank.

On November 14th samples of gas were aspirated for analysis from about 4 inches above the level of the liquid in the tank.

\begin{tabular}{|c|c|c|c|}
\hline & 'Time. & $\begin{array}{l}\text { Volume contrining } \\
\text { equal weights of } \mathrm{CO}_{2}\end{array}$ & $\begin{array}{l}\text { Percentages } \\
\text { of } \mathrm{CO}_{2}\end{array}$ \\
\hline 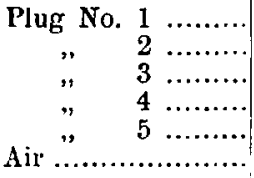 & $\begin{array}{l}11.25 \text { a.m. } \\
11.50 \text { ". } \\
12.10 \text { p.m. } \\
12.20 \text { " } \\
12.30 \text { a." } \\
11.15 \text {.m. }\end{array}$ & $\begin{array}{r}1 \cdot 8 \\
1.2 \\
1 \cdot 4 \\
1 \cdot 7 \\
1 \cdot 3 \\
24 \cdot 4\end{array}$ & $\begin{array}{l}0 \cdot 54 \\
0 \cdot 81 \\
0 \cdot 70 \\
0 \cdot 57 \\
0 \cdot 75 \\
0.04\end{array}$ \\
\hline
\end{tabular}

Average amount of carbonic acid in air of tank $=0.67 \%$. 
The presence of these appreciable quantities of gases containing carbon in the tank and tank effuent undoubtedly proves that considerable purification of the sewage in the tank takes place. Since the date of the above experiments the tank has been made air-tight, and the gases formed have been led off by a pipe and ignited. So that it would be possible for the combustible gases produced to be regularly burnt if a gas holder to regulate the pressure were used.

As the amount of increase in the total solids in the first set of experiments might have been due to the suspended matters in the samples examined-although one would have anticipated more suspended matter in the raw sewage than in the effluent after sedimentation had taken place-a further new series of experiments was started on November 13 th, and the samples analysed after filtration. The mean results calculated to a chlorine content of 7 parts per 100,000 are as follows :-

\begin{tabular}{|c|c|c|c|c|c|c|c|c|}
\hline & 至总 & $\begin{array}{c}\text { Orrgen } \\
\text { con- } \\
\text { sumed. }\end{array}$ & $\begin{array}{c}\text { Free } \\
\mathrm{NH}_{3} .\end{array}$ & $\begin{array}{l}\text { Alb. } \\
\mathrm{NH}_{3} \text {. }\end{array}$ & Nitrite. & $\underset{\text { Nitrate. }}{\mathrm{Nag}}$ & Total N. & 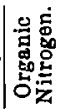 \\
\hline Filtered Samples- & & 1 & & & & & & \\
\hline Raw Sewage, Nov. 13,14 . & 55 & $3 \cdot 61$ & $8 \cdot 5$ & 43 & Trace & 0.02 & $12 \cdot 82$ & $5 \cdot 8$ \\
\hline Effluent, Nov. 14, $15 \ldots \ldots$ & 59 & $2 \cdot 73$ & $11 \cdot 2$ & $2 \cdot 66$ & Trace & 0.022 & $14 \cdot 92$ & $5 \cdot 7$ \\
\hline
\end{tabular}

It will be seen that the above results give the same general conclusions as were arrived at from the former series, viz., an increase in the total solids, 25 per cent. of organic matter destroyed, an increase of 33 per cent. in the free ammonia, and a decrease of 35 per cent. in the albuminoid ammonia. The total nitrogen, however, in this series shows a slight increase due to the larger amount of ammonia found in the effluent, or summarising-

Purification effected by Tank.

Oxygen Albuminoid consumed. ammonia.

$\begin{array}{rrrrrrrl}\text { 1st Series } & \ldots & \ldots & \ldots & \ldots & \ldots & 33 & \mathbf{5 4} \\ \text { 2nd Series } & \ldots & \ldots & \ldots & \ldots & \ldots & 25 & 38 \\ \text { Meanl } & \ldots & \ldots & \ldots & \ldots & 29 \% & 46^{\circ} \%\end{array}$

The Rivers Pollution Commissioners, after an examination of the various processes of chemical precipitation then known, cime to the conclusion that the average amount of purification was $28 \cdot 4$ per cent. Org. C. and $36 \cdot 6$ Org. N. 
The septic tank seems therefore to effect as much purification as an average chemical precrpitation process, or as slow upward filtration. It will be further noted that both sets of experiments show an increase in the total solids in solution of frum four to eight per cent., and this can only be explained on the hypothesis that the solid faces and other matter in suspension pass into solution in the septic tank.

Taling the population as 2,000, the weight per ammum of solid faces may be estimated as $1,300 \mathrm{cwt}$., containing 2 cwt. of organic nitrogen, whilst 170 cwt. of organic nitrogen will exist in the corresponding urine. These quantities correspond to a daily production of $40(0)$ lbs. of solid faces, containing $5 \cdot 7$ lbs. of nitrogen, together with 46 lbs. of dissolied nitrogen, chiefly in the form of urea, which on 50,000 gallons corresponds to 80 parts of solids per 100,000 , containing $1 \cdot 12$ parts of nitrogen per 100,000 , associated witl $9 \cdot 2$ parts of dissolved nitrogen and 4.6 parts of chlorine per day.

Solid freces contain 75 per cent. of water, and therefore the possible weight capable of increasing the total solids in solution would be $100 \mathrm{lbs}$. per day, or 20 parts per 100,000 . Then it is remembered that at least $15 \mathrm{lbs}$. of carbon are lost per day, as carbonic acid, or 3 parts per 100,000, or sar 6 parts of organic matter clissolred in the efthent, it will be scen that from 10 to 14 of these 20 parts of solids entering the tank in suspension have been accounted for, excluding any estimate of the considerable quantities of marsh gas, hyclrogen and nitrogen which are erolved as gas.

The 400 lbs. of solids daily may be estimated as having a volume of $\frac{1}{i}$ cubic yard, and consequently, if no allowance be made for any dissolution, the minimum time required for this quantity to fill up the septic tank would be nearly three years. The experience of Mr. Scott-Monerieff with his cultivation tank and of Mr. Cameron with his experimental septic tank, has been that after long periods of working, the small quantity of residual substance consists of a fincly divided inert matter, which seems allied to humus and peat, and is probably similar to the final nitrogenous compound noticed by Adeney in his experiments on sewage, and which seems necessary for the subsecpuent nitrification process.-(Adeney, Proc. Roy. Soc. Dul., Sept., 1895.)

Although the changes in the tank or in upward filtration are necessarily for the most part anacrobic, there is eviclence that a small amount of aerobic change takes place. Thus in some cases, nitrates and nitrites in small quantities are found in raw sewage; in the septic tank effluent they are both almost invariably present, and Adeney has shown that from the 
earliest stages of an aerobic fermentation of a strong solution of pure uren, nitrous nitrogen is produced in addition to ammoniacal nitrogen. The two changes can therefore go on simultaneously, and even when entirely under aerobic conditions, the first cliange-viz., conversion of organic nitrogen and carbon to ammonia and carbonic acid-precedes the second change, which consists in the conversion of the ammonia into nitric and nitrous acirls. The small portion of organic matter which is always converted during the first change into brown humous bodies, has considerable stability, and, as Adeney has pointed out, seems to be a determining factor for the nitric fermentation of ammonia, since in its absence nitrous acid only is obtained.

It is obvious that in a chemically treated sewage, or in a process such as that of $\mathrm{Mr}$. Waring, this first change must take place on the surface of the filter-bed or sewage farm before nitrification can set in, and that hence nitrous rather than nitric changes are more possible under these conditions than when the initial change has taken place before such treatment. The longevity of a filter-bed or the activity of a sewage farm soil, must therefore depend upon the rate at which this initial change takes place, and introduces an element of uncertainty into their working. The much better results which have been obtained by modern filters, as compared with the intermittent filters using raw sewage, as originally plamned at Merthyr Tydvil, can be explained in this way.

The conditions for the successful working of a filter bed, so as to ensure the production of nitric nitrogen when the effluent to be treated is rich in ammonia and free from undissolved organic matter, are well known, and Mr. Dibdin's London Comnty Council experiments with chemically treated effuent hive now so confirmed these conclusions, that it cannot be doubted that artificially constructed filters will rapidly take the place of the more expensive and less uniform sewage farms.

The experience gained on sewage farms, and the study of nitrification by bacteriologists have further shown that in the case of land treatment, different soils have very varying efficiencies. Thus the earlier experiments seemed to show that the "cleansing power" of a soil was determined entirely by its physical condition, porosity, freedom from clogging, water-retaining power, \&c.; whereas, at the present time we know that the composition of the soil and its bacterial efficiency modify the results.

Thus Dr. Frankland in 1870, in reference to a soil from the sewage farm at Barking, says, "These highly remarkable results show that there are soils in which the process of nitrification either does not take place at all, or goes on with 
great difficulty," and with regard to a loam from Dursley in Gloucestershire he found that it surpassed all others experimented on in its power of purifying sewage, as it had a cleansing power of nearly 100,000 gallons per acre per day. Althongh at that time the chemical composition of the soil was believed to have no influence on the result, the Dursley soil above referred to contained as much as $\checkmark \cdot 1$ per cent. of carbonate of lime, whereas that at Barking contained under 2 per cent., and we now know that the presence of carbonate of lime or of gypsum is favourable to the growth of the nitrifying organisms.

In a recent inquiry in which alternative sites were available for a sewage farm I obtained the following results :

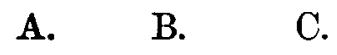

$\begin{array}{llllll}\text { Percentage of water } & \ldots & \ldots & 6.75 & 1.90 & 3 \cdot 05\end{array}$

Parts of nitric nitrogen produced per

100,000 parts of soil in 5 days on dilute urine $\quad \ldots \quad \ldots \quad \ldots$

$\cdot 168 \quad \cdot 504 \quad \cdot 36$

showing that the least water-logged soil, B., was also the most active bacteriologically. With efthents which have becn chemically treated with lime, there is probably sufficient alkaline base to farour the growth of the nitrifying organisms, even when the soil or the filter bed is devoid of such base.

In an analysis of samples of soil from a sewage farm in Surrey, where the soil, a ferruginous sandstone, is very deficient in lime, the calcium carbonate had increased by the treatment of the land with sewage, and thereby the quality of the effluent or purification was increased.

I.

II.

III.

Land before After 18 months. After 18 months.

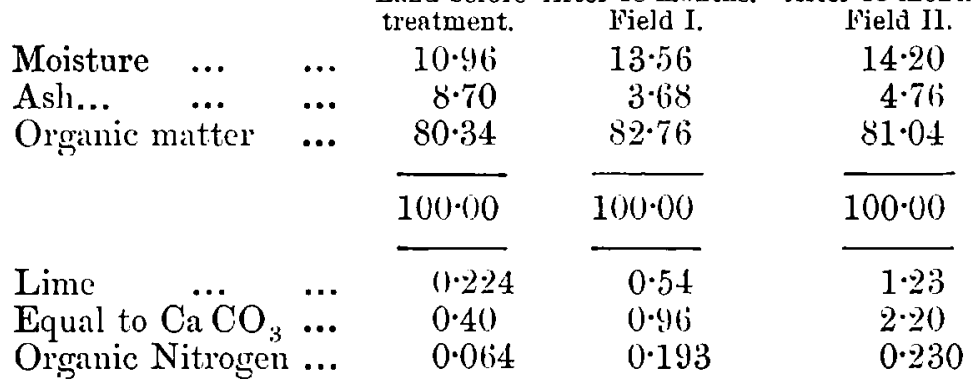

With filter beds it may be necessary in dealing with sewages of districts supplied with soft water, and in which lime is not 
employed in the chemical treatment, to add limestone or chalk to the filter bed in order to get the maximum results.

In some filter experiments on the small scale which I have recently carried out, the loss of nitrogen during filtration, and the influence of carbonate of lime in assisting the oxidation of nitrogen, are clearly seen.

A series of experimental filters of about one gallon capacity were fitted respectively with beds of gravel, coke breeze, and sand, each was seeded with 50 grains of garden soil containing 0.01 per cent. of nitric nitrogen. Water containing 10 parts per 100,000 of ammonia in the form of ammonium sulphate, and 10 parts per 100,000 of chlorine as sodium chloride, was passed through with daily intervals of rest. The sand, from the closeness of its particles, showed the least nitrifying effect. Three of the filter berls were mixed with 1 per cent. of chalk, the others had no chall.

\begin{tabular}{|c|c|c|c|c|}
\hline & Date. & Free $\mathrm{NH}_{3}$ & $N$ as vitrate. & Nitrite. \\
\hline $\begin{array}{c}\text { Gravel } \\
\text { without } \\
\text { Chalk }\end{array}$ & $\begin{array}{l}\text { Oct. } 22 \mathrm{gd} \ldots . . . \\
27 \text { th...... } \\
\text { Nov. } 11 \text { th...... }\end{array}$ & $\begin{array}{l}7.01 \\
7 \cdot 5 \\
4 \div 5\end{array}$ & $\begin{array}{l}1.28 \\
0.102 \\
0.052\end{array}$ & $\begin{array}{l}\text { Distinct. } \\
\text { Very heavy. }\end{array}$ \\
\hline $\begin{array}{l}\text { Gravel } \\
\text { with } \\
\text { Chalk. }\end{array}$ & $\begin{array}{l}\text { Oct. } 22 \mathrm{nd} . \ldots . . \\
\text { Nov. } 27 \text { th...... } \\
\text { Nov. } 11 \text { tl...... }\end{array}$ & $\begin{array}{l}5 \cdot 75 \\
160 \\
4 \cdot 25\end{array}$ & $\begin{array}{l}2 \cdot 11 \\
2 \cdot 23 \\
4 \cdot 65\end{array}$ & $\begin{array}{l}\text { Trace. } \\
\text { Distinct. }\end{array}$ \\
\hline $\begin{array}{l}\text { Coke } \\
\text { without } \\
\text { Chalk. }\end{array}$ & $\begin{array}{l}\text { Oct. } 22 \text { nd...... } \\
\text { "27th...... } \\
\text { Nov. } 1 \text { ith...... }\end{array}$ & $\begin{array}{r}10 \cdot 0 \\
1.0 \\
50\end{array}$ & $\begin{array}{l}1 \cdot 66 \\
0 \cdot 38 \\
0 \cdot 04\end{array}$ & $\begin{array}{l}\text { Trace. } \\
\text { High. } \\
\text { Excessive. }\end{array}$ \\
\hline $\begin{array}{l}\text { Coke } \\
\text { with } \\
\text { Clialk. }\end{array}$ & $\begin{array}{l}\text { Oet. } 22 \mathrm{nd} . . . . \\
\text { N" } 27 \text { th...... } \\
\text { Nor. } 11 \text { th...... }\end{array}$ & $\begin{array}{l}8 \cdot 75 \\
7 \cdot 25 \\
5 \cdot 0\end{array}$ & $\begin{array}{l}1.83 \\
1.51 \\
\ldots \ldots .\end{array}$ & $\begin{array}{l}\text { Distinct. } \\
\text { High. } \\
\text { Excessive. }\end{array}$ \\
\hline
\end{tabular}

These experiments point to the following conclusions :-

1. A rapid and continuous loss of ammonia occurs, which is not accounted for by the amount of nitrate or nitrite formed.

2 . The presence of carbonate of lime in the proportion of one per cent. greatly favours the production of nitric, as distinguisher from nitrous acid, and therefore a healthy condition of oxidation.

3. That a gravel soil with a sufficient calcareous aclmixture effects a rapid reduction in the amount of nitrogen present, which seems equal or superior to that of coke breeze.

4. That it is possible for a reversion of already formed nitric nitrogen to nitrite, and possibly to free nitrogen or oxide of 
nitrogen to take place in such filters when the conditions are unfavourable.

It is umnecessary for me to refer at length to the very valuable results in filtration which $\mathrm{Mr}$. Dibclin has now obtained after three year's' working under varying conditions, as these are now so well known. I should like, however, to draw attention to Mr. Thudichum's resume of the work done by the County Council in his paper before the Society of Engineers on Monday, December 7 th, 1896, in which he has so well advocated the use of such filters as a substitute for sewage farms, that I feel a repetition of his arguments on my part would be unnecessary.

There are, however, a few points in commection with the filter beds in use at Exeter which may not be out of place in this discussion.

The Exeter Filter Beds.-The effluent as drawn from the slotted pipe of the septic tank flows in a thin stream over an "acrator" (Plate I., p. 64) or trough over the edge of which it falls, finely divided, into a receptacle communicating with the filters. At the "aerator" the eftluent which emerges fiee from dissolved oxygen takes up atmospheric oxygen amounting to $0.56 \mathrm{cc}$. per litre, or about 10 per cent. of the quantity theoretically possible, before passing into the filter beds. This preliminary aeration is, I think, worthy of every consideration, as it obviously is an important aid in supplying the necessary oxygen for the successful working of the tilters.

The construction of the filter beds and material used in them do not call for any special remarks, as they have been constructed on well-linown lines (Plate III., p. 64) and follow the conditions for successful working which have been established by the Massachusetts Experiments, and more recently in this country by the London Comnty Council under Mr. Dibdin's advice at Barking. In the latter case the removal of 75 per cent. of the oxidisable organic matter's in solution in the chemically treated London sewage was effected by filtering $1,(0) 0,000$ gallons of efthent per day through a coke breeze filter of one acre. 50,000 gallons consequently require 200 cubic yards per day, and this is approximately one-half the filtering volume available at Exeter, excluding a reserve filter bed of about 133 cubic yards capacity.

By means of an automatic gear the effluent is clistributed on to the filters in such a way that periods of aeration are ensured. The mechanical arrangements are of such a nature as to work efficiently with varying flows and permit of constant and regular filtration (Plate IÍ., p. (34). This method of working is sufficiently explained in the diagram. 
Repeated examinations of the filtrate from the several filter beds have shown that nitrates are prodnced in appreciable quantities in the effluent. During the periods of rest, when the filters, although apparently empty, contain a very considerable fraction of the total rolume of effluent absorbed in the coke breeze, carbonic acid is produced in large amounts (see Table); and it is more than probable that it. is during the "empty stage" that the greatest amount of nitrification takes place.

\section{TaBLe.-Amount of Carbonic laid produced in an Empty Filter.}

On November 12th, "compo" tubes were sunk to different levels in Filter No. 2, which had been in constant work for several days, and the gases aspirated for analysis two or three hours after the last discharge.

\begin{tabular}{r|c|c|c|c}
\hline & Air. & $\begin{array}{c}\text { Tube 1, } \\
18 \text { in. }\end{array}$ & $\begin{array}{c}\text { Tube 2, } \\
36 \text { in. }\end{array}$ & $\begin{array}{c}\text { Tube 3, } \\
\text { j4 in. }\end{array}$ \\
\hline $\begin{array}{r}\text { Per cent. of Carbonic Acid by } \\
\text { Volume ........................ }\end{array}$ & 0.04 & 0.375 & 0.98 & 0.75 \\
Relation to Volume in Air...... & 1 & 0.4 & 24.4 & 18.8 \\
\hline
\end{tabular}

Assuming the air in each empty filter to contain $1 \%$ of carbonic acid, we have 80 gallons of carbonic acid in ench filter, or about 400 gallons produced per day. The weight of organic carbon destroyed per clay in this way is therefore about $2 \frac{1}{2}$ lbs. No experiments were made to determine the amount of dissolved carbonic acid produced in the filters, but this must be considerable.

The curves given in Plate IV., p. 64, show the variation in the amount of nitric nitrogen in the filtrate. After a period of long rest, the greatest amount of nitric nitrogen makes its appearance in the first rumings, showing that it is during the period of rest that the nitric acid is formed. Analyses of the liquid rising in the "wells" on filling a filter when the residual liquid is being displaced, show nitric nitrogen of from three to five parts per 100,000 in many instances.

Dr. Sims Woodhead, who has examined the process bacteriologically, has also formed a similar conclusion from his experiments.

In order to arrive at an estimate of the further purification effected by the filters, it is necessary to compare the filtrates 
produced from raw sewage and tank effluents of known composition, and for this purpose the filter-bed discharges corresponding to the two periods already examined have been averaged and submitted to analysis. The change effected is summarised in the following Table, the filtrates, as in the case of the raw sewages and tank effluents, being calculated on a chlorine content of seren parts per 100,000 .

\begin{tabular}{|c|c|c|c|c|c|c|c|c|}
\hline & $\begin{array}{l}\text { Total } \\
\text { Solids. }\end{array}$ & $\begin{array}{l}\text { Oxygen } \\
\text { con- } \\
\text { sumed. }\end{array}$ & $\begin{array}{l}\text { Free } \\
\mathrm{NB}_{3}\end{array}$ & $\frac{A l b .}{N u_{3}}$ & Nitrite. & $\begin{array}{c}\mathrm{N} \text { as } \\
\text { Nitrate. }\end{array}$ & $\begin{array}{c}\text { Organic } \\
\text { Nitro- } \\
\text { gen. }\end{array}$ & $\begin{array}{c}\text { Total } \\
\mathrm{N} .\end{array}$ \\
\hline 1st Series-- & & & & & & & & \\
\hline Raw Sewage ... & $46^{\circ} 8$ & 656 & $3 \cdot 6$ & 1.40 & None & None & 44 & $7 \cdot 4$ \\
\hline $\begin{array}{l}\text { Tank Bffluent ... } \\
\text { Filtrate .............. }\end{array}$ & $48 \cdot 6$ & 432 & $\begin{array}{l}4.9 \\
.1 .9\end{array}$ & 0.64 & Tre & $\begin{array}{l}.041 \\
.30\end{array}$ & $2 * 2$ & 604 \\
\hline 2ud Series-.. & \pm & 0 & -40 & 070 & Mrnce & 00 & - & $I 0$ \\
\hline Raw Sewage & $55 \cdot 0$ & $3 \cdot 61$ & $8 \cdot 5$ & $4 \cdot 3$ & Trace & $\cdot 02$ & $5 \cdot 8$ & 1282 \\
\hline Tauk Effluent ... & $59 \cdot 0$ & $2 \cdot 73$ & $11 * 2$ & 266 & Trace & .022 & $5 \cdot 7$ & 1492 \\
\hline Filtrate ............ & $49 \cdot 9$ & $1 \cdot 13$ & $6 \cdot 05$ & 0.87 & Heavy & 1.06 & $4 \cdot 4$ & $10+16$ \\
\hline
\end{tabular}

The above results show that the filter beds effect a considerable reduction in the organic matter both as measured by the oxygen consumed and albuminoid ammonia methods, and at the same time further effect the removal of a large percentage of the free ammonia, and the production of abundance of oxidized nitrogen in the form of nitrite.

The percentages of purification effected in the two series calculated on the raw sewage and on the tank effuents are shown in the following table:-

I. Purification due to filters.

Oxygen consumed.

$73 \%$
Albuminoid Ammouia.

$60 \%$

II. Purification due to septic tank and filters.

$$
82 \% \quad 77 \%
$$

The purification effected by the tank on the raw sewage (see ante) being $29 \%$ and $46 \%$ respectively. It will be noticed that the purification due to the filters is $73 \%$, or practically identical witl that shown by $\mathrm{Mr}$. Dibdin $(75 \%)$, as possible with coke breeze on chemical effluents. Tho process is therefore almost identical in its results with that of the combined chemical treatment and filter as used at Barking, the septic tank effecting $29 \%$ purification as against the Rivers Pollution Commissioners' mean result of $28 \cdot 4 \%$ removal of organic carbon by all the best known chemical methods, and 
the filters yielding $73 \%$ purification on the tank effluent as compared witl $75 \%$ purification obtaincd by $\mathrm{Mr}$. Dibdin in the same way on a chemically treated effluent.

It will be noted that the filtrates during our experiments still contain some free ammonia and albuminoid ammonia higher than that furnished by the London filtrates, or admissible under the proposed standard of 3 organic nitrogen suggested by the Rivers Pollution Commission.

This is due to the fact that the tank effluent is stronger that the chemical effluent dealt with at Barking, so that although the percentage purification is the same, the final impurities remaining are greater.

It is, however, necessary to point out that the filtrate is in an exceedingly active condition, containing obviously abundance of nitrifying organisms, and also no less than $2 \cdot 85 \mathrm{cc} . \mathrm{s}$ per litre of recently dissolved oxygen, or 40 per cent. of the maximum possible, introduced into the filtrate by the method of discharge. The filtrate, therefore, without any further treatment, is capable of self-purification, and this change is so rapid that in less than twenty-four hours the slight odour noticed in some of the filtrates entircly disappeared, and the nitrates increaserl to a much higher figure. In most analyses the interval of time between sampling and analysis is very much greater than in these cases, in which the filtrates were analysed in some instances only a few moments after collection. I believe that the results hercin recorded are therefore more unfavourable to the process than if the analyses had been made less quickly after collection. Thus, for example, an average filtrate on November 14 th gave on analysis 0.406 nitric nitrogen per 100,000 , but when analysed on November 18 th the amount had increased to $0 \cdot 882$. Similarly a sample collected on Nov. 13 tl, and analysed on the same day, gare $3 \cdot 56$ nitric nitrogen, whilst on November 18 th the amount had risen to $5 \cdot(45$.

This self-purification takes place in all filtrates from filter beds, especially if the filtrates are aerated during the discharge. This process is so well known that I need not discuss it at length, but I should like to insist upon its importance, as $\mathbf{M r}$. Scott-Moncrieff, in his nitrif ying chamnels, relies solely on such a change for the final purification of his effluent. This he accomplishes by mixing his cultivation bed effluent with river or brook water to supply further oxygen if necessary, and then allowing it to pass through an open channel filled with coke. The purification of sewage-polluted rivers like the Isar at Munich, Zimmat at Zurich, and the Spree at Berlin, have also recently been shown to be effected in an analogous manner.

A filtrate in what may be regarded as an active bacterial 
state can certainly be discharger into a river or a water-course without danger, and our present knowledge certainly warrants some modification in the standard of purity of such discharges. The standard of 0.3 parts per $100,00()$ of organic nitrogen sometimes insisted upon was nerer legalised, and has seldom been lived up to even on well-managed sewage farms at all seasons of the rear, and is not adopted by the Thames Conservancy, which at present may be regarded as the most exacting authority in England.

Adeney in the paper already referred to has suggested a simple standard which conforms to modern requirements, and which might with advantage be aclopted by authorities. It is as follows :- " The limit of impurity to be allowed to a given water should be such, that, when a given volume of it is mixed with a given rolume of fully aerated water, and the mixture kept in a bottle out of contact with air for a sufficient length of time, a decieled oxidation of the ammonia originally present in the mixture into nitrous, or nitric acid shall be inclicated."

If some such standard as the abore were generally adopted, I believe it would tend to greater miformity of results, and give a broader basis for judging as to the merits or demerits of any system of sewage purification than we have at present. It would further show that it is possible to produce satisfactory eftluents without the use of lind, and would permit of the Local Goverument Board sanctioning schemes which would not only be more economical to execute, but be of a more satisfactory claracter than many sewage works of the present time, in which the best advice, both with regard to chemical treatment and land irrigation lias been followed.

The Chimman (Prof. W. H. Corfield) asked for the thanks of all present for Dr. Rideal's introduction of a subject of such importance. It seemed most interesting that processes should be brought forward whicls would tend to utilise phenomena already well known in connection witl the puritication of sewage. It had been long known that sewage stored in a tank would give off marsh gas, nitrogen, dc., but only quite recently had it vecurred to any one to turn this to account to liquefy the sludge. In all sewage disposal systems the difliculty was the disposal of the sludge, and any process which would treat this successfull; would be quickly taken up and prove of very considerable inportance. 
Mr. H. A. Roechling (Leicester) regarded the septic tank system as the forcing frames or forcing beds of nature in which nature was asked to do its work at express speed; and he would bid them be careful of how they proceeded lest they presently found they had produced a something over which they had no control. It would be well to wait until they knew more about the way in which the work was. effected, and the attitude of the Inspectors of the Local Government Board must commend itself to all who desired to see the object of sewage disposal advanced, yet objected to the expenditure of large sums of public money in experimeutal work. In the septic tanks they first putrefied the sewage and then delivered it into the filters, and to pour sewage after putrefaction had taken place on land had up to now been held to be wrong. Further, the provision of tanks for it one day's flow would prove inost expensive, and for a town the size of London simply prohilitive. He would like to know whether Dr. Rideal in the course of lis investigation and experiments at the Exeter septic tanks had observed the presence of any ptomaines in the effuent from the tanks, and whether these substinces bad been diminished by the filters; for if they were still present in the effluent from the filters he should think it very dangerous to discharge it into any brook or stream. Further: did some of the substances formed in the septic tank retard or accelerate the work of the filters: and was sulphuretted hydrogen formed? It seemed to him that the septic tank was sinuply a machine for the production of sewer gas of a very condensed nature. Turning to the filter beds, he was dismayed at the quantity of albuminoid ammonia present in the effluent, which was considerably above the standard suggested by the Rivers Pollution Commission and the standard now adopted by Sir Henry Roscoe for the Irwell and Mersey Joint Committee. The Berlin Siewage Farms had effected far more than the septic tank and filters, and the effluent from the broad irrigation plots contained, in an average of 71 analpses, omly 0.039 parts of albuminoid ammonia in 100,000: while the method suggested could not be rery much cheaper than the chemical treatment. According to Rolinson and MIellis the cost of the chemical treatment in five Euglish towns ranged from a rate of 1.80d. to a rate of $s 10$ d. in the $£ l$, whilst the cost of sewage irrigation in twenty-six English towns was on an average equal to a rate of $5 \cdot 84 d$. For Berlin the figure was about $0.89 \mathrm{~d}$., and for Breslau about $\frac{1}{2} \mathrm{~d}$., whilst the cost of the Leicester Farm for six years had been equal on an average to a rate of $3 \frac{1}{4} \mathrm{~d}$. in the $£$. If they could purify sewige at so cheap a rate they ought to be satistied. Besides in acquiring land for sewage farms the Corporation were acquiring real estate which would always have some value, whereas tanks and filters, after a treatment had been abandoned, wonld be worse than useless. So far as he was concerned, while thanking Dr. Rideal for his excellent paper, he felt it would be best to take up the attitude of benevolent observation. 
An enquiry was made as to whether the district of Exeter treated, contained any breweries, distilleries, or cliemical factories.

Mr. ScotT-Moxcrieff (London) remarked that when Sir Douglas Galton read his paper, about a year ago, on the experiments of the Massacliusetts Buard of Health, before the Institute, he (Mr. Moncrieff) ventured to predict that this subject of the purification of effete organic matter by means of micro-organisms would ere Inng be treated in the light of much greater knowledge than was then generally available. He thonght that the able paper which they had just heard quite justified that prediction, and the fact that this was the third which had been read before professional audiences in London within the past ten days was a proof of how greatly the subject had advanced in the estimation of the scientific public. He (MIr. Moncrieff) had carried out investigations on the purifying action of micro-organisms upon sewage on a practical scale in 1891: and in 1892 he showed that they were capable of dealing with the whole of the organic matter without previous deposition or straining. These investigations are set forth in a Report by Dr. Houston, published by Messrs. Waterlow Bros. in 1893, and it is an interesting fact that the original "cultivation" tanks, which were there deserihed, are still at work; and that, as the colonies of bacteria are subjected to a process which entails the survival of the fittest, their capacity for usefulness seems to increase as seeing that they are more efficient now than ever, and carry on their operations quite automatically. It is not to be wondered at that such an inexhaustible supply of natural and beneticent force as is represented by the life processes of these bacteria, should be looked at from the point of view as to how far they can be utilized for the service of man. Referring to the "septic" tank, the arrangement as described by Mr. Cameron had been in use in France and in this country for many years, and he had great doubt if it was equally eflicient as an apparatus which provided surfaces for the growth of the organisms. The secondary cultivation tanks used by $\mathrm{Mr}$. Cameron are dependant upon a large extent of well aerated surfaces for their action, and what was good for the organisms of nitrification must be equally good as regards the surfaces for the organisms of liquefaction, even if these were anaerobic in their character. Referring to a statement made by Dr. Rideal in his paper, while it is true that the process which he (Mr. Moncrieff) had advocated depends upon the change which occurs among the unstable organic matters in solution, when they are discharged uncler favourable conditions as to oxygen, so long ago as 1892 he had clearly indicated the applicability of duplicated or grouped "cultivation tanks" as used by $\mathrm{Mr}$. Cameron, and he had not confined himself to the use of aerating chamnels alone. In practice, time is an essential element, in the successful solution of the problem, and by doubling the activity of the process in any given case, it is obvious that half the tanks, etc., would be sufficient to attain the same standard of purity. 
He was the better able to congratulate the writer of the paper on the ability and ingenuity displayed in it, as he had been at work himself on the same subject for several years, and looked upon Dr. Rideal somewhat in the light of a pupil.

Mr. C. H. Cooper (Wimbledon) felt it to be a mistake in alluding to the upward filters not to credit them with nitrifiention.

Col. A. S. Jores (Finchampstead) would like to see the "Septic" or "Cesspool" system of treating sewage tried as fully as possible, for the whole question was complicated, and they lnew very little of the bacterial action in the breaking up of sewage. The microbe was the scavenger of nature, and they ought to watch its proceedings with deep interest. They had to purify the sewage, the bacterial action in the septic tank broke the matter up, and a great deal disappeared in the process: yet as the effluent was disagreeable smelling he would not like to have it on a sewage farm. Let them give the filter system a fair trial. At present they knew nothing of what is to be done with the mineral matter deposited in them, and the preliminaly expense must be very great. Where they could get land cheaply nothing could beat irrigation, but by all means let them go on with the experiments, moderately, but not rashly.

Dr. G. Ruid (Staffordshire County Council) said that being responsible for the supervision of a large number of sewage disposal works he was desirous of finding out the actual result which could be obtained from the septic tank treatment. It appeared to bim that the results were worse than those obtained by Mr. Dibdin with half the tank capacity and filter area. He could show a much better effluent, chemically, from an ordinary precipitation tank. With regard to the standard of purity adopited he considered tbat in the case of inland towns discharging into comparatively small streams 05 per 100,000 of albuminoid ammonia should not be exceeded. Staffordshire represented many other counties as regards general conditions, and taking the figures given them that evening he was disappointed with the results obtained by Mr. Cameron's experimental tank, and was of opinion that the system, although good from a sludge disposal point of riew, was by no means satistactory as regards the ultimate result.

Dr. G. V. Poone (London) said that with regard to the comparatively recent dates quoted as to the insistance on biological processes in relation to sewage disposal, it was now about ten years since he read a paper before The Sanitiry Institute dealing with the bacteriological aspect of the question. Looking at the construction of the septic tank under notice, one was inclined to say it was exceedingly ingenious, but he wanted to know something more about the solid matters in the sewage, for he could not believe that paper, string, rag, feathers, \&c., were dissolved. They could not furce nature, truly; what the engineer had hitherto tried to do was to thwart 
nature. They had heard nothing abıut the sulphuretted hydrogen evolved. The best effuents were obtained, he ubserved, when the filter beds were nearly empty; and they knew that in filtration directly a filter got fully charged the power of that filter ceased; the intermittent downward action must be almost constant. The septic tank appeared to him to resemble a fermenting ressel in a brewery. Some of the stuff floated to the top, like the frothy yeast, and some sank to the bottom, and a fluid tolerably free from suspended matter was drawn off between the tro. It clearly had one great advantage orer other systems inasmuch as no chemicals were added to the serrage to check the growth of those organisms (such as the Beggiatoa) which alone led to its oxidation, \&c.

Mr. J. P. Nornixgron (Surveyor to the Vestry of Lambeth) said that being a native of Exeter he had naturally talien some interest in the subject before the meeting and had seen the septic tank at work. He had visited a great number of works of a. similar kind in England, and he desired to testify to the efficiency of the system under discussion, the filtrate showing a degree of clearness and purification seldom seen elsewhere.

Mr. D. Cameror (Exeter) was invited to speak on the subject: and in responding said that the sewage received no prelimiuary straining; whatever goes along the sewer finds its way into the septic tank. Great difficulty was experienced in obtaiving suitable filtering material, and to get the work finished as soon as was possible, he had to take old clinker that had for a loug time lain in a market gardener's yard, only one of the filters being of coke breeze. On the 21st of August the works were started. He was desirous of knowing the actual water-capacity of the filters when the filtrate was dry and after being saturated. To do this the filters had to receive their full dose to begin with, instead of being gradually formed by small doses as recommended by $\mathrm{Mr}$. Dibdin. Instead of getting a day's rest each in seven, the shortest time that any filter worked, without intermission, was sixty-one days. The months of September and October were extremely wet, so that instead of dealing with the normal quantities of sewage they had to deal with twice and three and a half times that quantity, or at the rates of $1,300,000$ galls. per acre per day, and 1, 660,000 galls. per acre per day. And it was after such work and during a period of severe frost that the investigations of Drs. Rideal, Dupré, and Sims Woodhead were made. One of the dominant ideas he had in laying down his system was that it should be subjected to the severest treatment which it was likely to receive in practice-that in fact the works sbould be left to take care of themselves, and that was what practically was done, and he was not aware of any works that could be so left. During the investigations that were made he was surprised to find storm water's, after a continuation of wet weather, so high in organic pollution. $\mathrm{He}$ thought it would be found necessary, insteud of making provision for 
the reception of a certain part of an inch's rainfall for twenty-four hours, that an extreme case should be taken or that the worst condition should be provided for, such as a summer thunder shower after three, four, or tive weeks' drought. He had observed more destruction of fish life in half-an-hour under such conditions than would be found in years from the discharge of domestic sewage into a stream. At no time was the assistance of the chemist of greater importance to the engineer than in the question of dealing with the storm sewage of a populous district. Filters worked intermittently did not become inefficient by any clogging by solids carried over, but when overcharged by too frequent doses of effluent their water capacity becomes rapidly less and their efficiency almost ceases. Nothing is easier of demonstration than that sewage filters are not mere strainers. He had been deeply interested in the discussion and thanked them heartily for the remarks made.

Dr. S. RIDEAL (London), in acknowledging the vote of thanks accorded him, sajd that with regard to the results, it was not his practice to take a roseate view of things, and therefore bis conclusions were under-estimated rather than otherwise. The Local Government Board would not, of course, pass such a scbeme for large towns if they still continued to insist upon the purcbase of land at a certain fixed rate, dependent upon the population. The Exeter filters were on the lines of those at Massachusetts and at Barking; and at Exeter they had procured practically the same results as Mr. Dibdin. If it be insisted on that the albuminoid ammonia represents removable organic matter, it must be remembere? that it is in an easily decomposable state, and already associated with much dissolved tree oxygen, and active nitrifying organisms. It is, therefore, in a condition to put on to a very small area of land, or into another filter, for firther treatment. "So far, he had not obtained any eridence of the presence of ptomaines, but it will be seen that the process involved no new changes, but was under the same conditions as occurred in large irrigation systems, so that the compounds produced are identical; as the filter beds afford ample opportunity for oxidation, it is exceedingly probable that such compounds, if formed, are destroyed in the tilters. With regard to Mr. Roechling's question, nitritication is retarded by the substances formed in the tauk when the effluent is supplied too quickly, just as sewage badly treated chemically would prerent the proper efficiency of work on land. When, however, the right ratio of air and effluent was maintained, the filters should work continuously. Sulphuretted bydrogen is produced in the tank, just as it is produced in a sewer; but it was, he felt, far better to produce it in the closed chamber than on the land, or in a sewer where it might, and often does, create a nuisance. With regard to the argument that a lengthened stay in the filter bed would improve the filtrate, experience showed this was not so, the reverse being the case. 'i'be matter treated was the domestic sewage from

VOL. XVIII. PART I. 
a suburb of Exeter with a population of some 2,000. There were no chemical factories in the rnnge of the sewer, but he failed to see why, if the process could serve in one case, it should not do so in another. Mineral sludge was, of course, not dissolved, but by means of the grit ehamber it could be remored at any time; and as the progress of the serrage was so slow in the tank, the mineral matter would to a very large extent fall. The trouble in all processes was not with the mincral matter, which did not putrefy, but the sludge, which did. In the Exeter scheme there was no sludge difficulty, as even if the tank effected no solution of the suspended solicls, it would still act by sedimentation in a closed space and therefore without offence, and the particles could not reach the filters and so cause clogging. The putrescent liquids are delivered on to the surfaces of the filters and not below, after aeration has been effected by the sewage passing over a weir, as shown. He lad already observed that the evolved gases could easily be burnt and rendered inoffensive, and the heat produced might possibly be utilized. 